\title{
Strengthening Social Capital in Empowering Village Farming Communities in Padaherang District, Pangandaran Regency
}

\author{
Cucu Widayati ${ }^{1 *}$ Reski $\mathrm{P}^{1}$ Rahmat Nur ${ }^{1}$ \\ ${ }^{1}$ Department of Anthropology Sociology Education, Faculty of Teacher Training and Education, Lambung Mangkurat \\ University, Banjarmasin 70123, Indonesia \\ *Corresponding author. Email: cucu.widaty@ulm.ac.id
}

\begin{abstract}
This study describes the strengthening of social capital in the empowerment of rural farming communities in Padaherang District, Pangandaran Regency. This is because the life of the farmers community is increasingly questioning, such as the lack of interest in becoming a farmer, the high number of poor farmers, increasing low education, and increasing access to training and assistance, leaving farmers powerless and without independence. This study aims to obtain a picture of strengthening social capital in empowering rural farming communities in Padaherang Subdistrict, Pangandaran Regency. The research method used in this research is the case study method by obtaining qualitative. The results of the study can be known about the five-group program formed, namely the Kelompok Tani Sejahtera (KTS), Kelompok Wanita Tani (KWT), Pelatihan Anak Tani Remaja (PATRA), Pengembangan Usaha Agribisnis Perdesaan (PUAP), and Gapoktan (Gabungan Kelompok Tani). These programs are the result of the formation of self-supporting farmer communities on the basis of a fate and challenges to the problems experienced by village farmers. Farmers feel the quality improvement goes up to a better direction. Farmers are more interested in increasing their knowledge, skills and expertise in agriculture. Farmers are guided to have more independence, ability to solve problems, be able to think, and fit in accordance with their experiences found in the program activities. Social capital supports the empowerment of farmers with the social network that is in it related to members with a relationship of mutual trust, high solidarity, upholding social values and norms, reciprocity and profitability.
\end{abstract}

Keywords: community empowerment, social capital, village farmers

\section{INTRODUCTION}

The figure of the farmer in the village is a characteristic that is very closely embedded in the rural community. The style of rural communities with the lives of farmers is inseparable from one another. The majority of rural communities live depending on agricultural livelihood patterns [1]. Agricultural life is also supported by the environment with large tracts of land, climate, population, and the social culture of the rural community itself. Agriculture is a mainstay sector to improve the welfare of some rural communities. This is what makes agricultural productivity very important for rural communities, in addition to supporting food self-sufficiency as well as a source of daily economy [2].

One of the characteristics of the village community is that life is highly dependent on agriculture as the main source of income [3]. So it can be said that the agricultural sector is a primary component as well as having an important role in sustaining the lives of rural communities. Rural areas are areas that have the main activities of agriculture including natural resource management with the arrangement of the function of the area as a place for rural settlements, government services, social services, and economic activities [4].

The position of farmers in this case is as a caretaker, manager, and farmer developer in the village. Implementation of the success of farming that farmers do basically depends on the participation of all elements of the community itself [5]. Based on statistical data, currently around $75 \%$ of Indonesia's population lives in rural areas, and more than $54 \%$ of them depend on agriculture for their livelihoods [6]. According to data reported by the Central Statistics Agency for West Java Province in 2018 through the 2018 inter-census agriculture survey (SUTAS), the total number of farmers in West Java was $3,821,603$, with details of 2,969,448 male farmers and the number of farmers as many as 852,155 inhabitants [7]. This shows that the number of farmers is very small compared to the total population of West Java which reached 49.02 million people and shows a decline in the number of farmers around 10-20\% every year.

Padaherang is a sub-district located in Pangandaran Regency. Padaherang District has the most extensive farmland compared to other districts in Pangandaran Regency, which is 1,365 Ha. In addition, Padaherang sub- 
district is known to have fertile land and is free from flooding. So it is not wrong if the sub-district of Padaherang is nicknamed "the village of rice granaries". This of course can be an opportunity if the farmer can maintain and improve the quality of agriculture but on the contrary it will be a challenge for all elements of the village community if the farmers show a decrease in quality even to the decline in the number of farmers. So it can be said that Padaherang sub-district is an area that has potential but also has various obstacles. The data further states that the number of farmers in Padaherang subdistrict is 11,958 people with a total population of 62,726 people (Source: data from the Central Statistics Agency in Pangandaran Regency in 2018). So it can be said that the number of farmers in the District of Padaherang is very minimal at only $20 \%$.

The decline in the number of farmers in West Java, especially in the District of Padaherang is an important problem that poses a threat to the survival of the agricultural sector in the village. Reflected by the state of regeneration of farmers that are not running properly. It is known that there are only 1,257 farmers in Padaherang sub-district (15-30 years old). Young educated people are reluctant to become farmers. The world is currently experiencing a crisis of workers in agriculture, the younger generation is no longer interested in becoming farmers. This has been very worrying, therefore it is very necessary to have an empowerment that focuses on a young generation approach strategy by preparing and optimizing the capabilities of existing resources [8].

Another problem experienced by farmers in Padaherang sub-district is the achievement of their formal education which is still low. Based on the monograph data of Padaherang sub-district in 2018, formal education for farmers consisted of 5,381 people or $45 \%$ of elementary school education, 4760 people or $40 \%$ of junior high school education, and 1785 people or $15 \%$ of high school education. Based on the observations of previous researchers, the majority of farmers in Padaherang subdistrict are classified as elderly who have low education so that the quality of farmers' resources is also low. With limited knowledge, farmers still use traditional methods without technological innovation in managing their farmland. Therefore there is a need for empowerment that focuses on strengthening social capital in the form of training, education and skills about knowledge and expertise in productivity, efficiency, and innovation in agriculture.

The high contribution of the agricultural sector in the village is not followed by the welfare of farmers as the main actors driving the agricultural sector. The irony is that the lives of farmers are still far from feasible with the majority of farmers still below the poverty line. The life of farmers in the countryside is closely linked to poverty". One of the fundamental factors causing poverty is the lack of optimal social capital with weak resources. The low mastery of productive resources and the low quality of human resources so that food yields are less prosperous for farmers [9].
According to the researchers' observations, farmers in Padaherang sub-district are still struggling with the problem of misery that does not end, such as the limitations of farmers in obtaining capital. Uncertain agricultural income makes it difficult for farmers to get financial services. Formal institutions such as banks and cooperatives are not easy to provide loans to farmers without collateral. Farmers are considered unable to meet monthly payments because it is not in accordance with farming that provides a seasonal production cycle. In addition, poverty that always lurks farmers in the village is also caused by crop failure, unbalanced prices and market access.

Lack of farmers' access to training and counseling is also experienced by farmers in Padaherang sub-district. The limited farmers in gaining knowledge in farming causes low productivity which affects their income. Therefore, the farming community really needs the empowerment of social capital in which it provides training, assistance and development. This is to improve the Human Resources (HR) of farmers based on the potential and ability of their communities so as to realize the life of an independent, developed and prosperous village farmer community.

The problem of the decreasing number of farmers, poverty, and lack of access is a challenge. These challenges must be faced and responded to so that the problem is not sustainable and can be resolved as quickly as possible. One response (response) to the reduction in the number of farmers, poverty, and lack of access is that there must be a program that can provide strengthening social capital owned by empowering the community, so as to solve the problems it faces. The development of the program aims to maintain the social infrastructure of farmers that can be a glue or social cohesion, turn on social cultural support such as mutual cooperation in the community through integrated empowerment, and the formation of social institutions with dynamic membership and participation of farmers and become a vehicle or vehicle social participation [10]. Community organizations are businesses that aim to empower people and encourage them to be active agents of community change [11]

Social capital is the key to the success of a community empowerment program. Social capital refers to forces that increase the potential for economic development in a society by creating and maintaining social relations patterns of social organization. This is the process of networks, values, and trust that arise among the members of the association, which facilitates coordination and cooperation for mutual benefit. This empowerment is very important to reduce inequality which will have an impact on the equalization and improvement of the quality and quantity of agriculture in Padaherang sub-district that are competitive at national and international levels. This is believed to be the key to the welfare of rural farmers. Therefore the researcher wants to discuss the problem of how to strengthen social capital in empowering the village farming community in the Padaherang sub-district of Pangandaran Regency. 


\section{METHOD}

In conducting an analysis of the strengthening of social capital in the empowerment of the village peasant community in the Padaherang sub-district of Pangandaran, the researcher must look directly at the informants in daily life in the form of the whole social situation which includes aspects of the place (place), actors (actors) and activities (activity) that interacts synergistically. In this study, the researcher also wanted to reveal the relationship that was fostered between the agency and the village community, especially the farmers, as well as the behavior change caused by the empowerment of the program. To explore the issues examined in depth and naturally, this study used a qualitative approach. Qualitative research are methods for exploring and understanding the meaning by a number of individuals or groups of people ascribed to social or humanitarian problems [12].

The research approach used by researchers uses the case study method to reveal the social relationships that exist between empowerment agencies with the community and farmers. Case research is an intensive, detailed and indepth study of a particular institution, organization or phenomenon. Case research is an intensive, detailed and in-depth study of a particular institution, organization or phenomenon [13].

\section{RESULT AND DISCUSSION 3.1 Efforts in Empowering Peasant Communities}

Strengthening social capital in empowering the village farmers community is carried out in several forms of programs, namely the Kelompok Tani Sejahtera (KTS), Kelompok Wanita Tani (KWT), Pelatihan Anak Tani Remaja (PATRA), Pengembangan Usaha Agribisnis Perdesaan (PUAP), and Gapoktan (Gabungan Kelompok Tani). These programs are the result of the formation of non-governmental farmers based on the fate of the continuity and concern for the problems experienced by village farmers. People who have the same fate, goals, and ideals will tend to group and form a community to achieve the expectations they want to achieve [14]. In this case the community still needs assistance, direction, and instruction, because empowerment basically gives strength or efforts from those who have power to the people who are powerless or capable, therefore the role of empowerment agents is very vital in supporting the success of community empowerment. Interaction enables people to build communities, commit to one another, and weave social order. The sense of belonging and concrete experience of social networks (and the relationships of trust and tolerance that can be involved) can provide great benefits for the people involved in them [15].

Based on the Law of the Republic of Indonesia Number 19 of 2013 concerning Protection \& Empowerment of Farmers in Article 1 Paragraph 2 written understanding of empowerment of farmers which reads "empowerment of farmers is all efforts to improve the ability of farmers to carry out better farming through education and training, counseling and assistance, development of systems and means of marketing agricultural products, consolidation and guarantee of agricultural land area, easy access to knowledge, technology and information, as well as strengthening institutional farmers [16]. Farmers need to be given protection and empowerment so that farmers have the capacity to continue to grow and develop to become more prosperous.

These programs seek to mobilize and excite farmers in running their farming businesses. Farmers look enthusiastic and enthusiastically welcome farmers to participate in various activities held in the program. The farming community strives as much as possible for itself and for the surrounding community to be more independent and empowered. According to them, the program that was launched was very useful because it was in accordance with the needs of farmers in improving their economy. Example in the Kelompok Tani Sejahtera (KTS) program there are TAMBULAPOT activities which can add to their income. Farmers are very well directed through these programs, for example they can maximize their resources and potential. Farmers have more insight and are open-minded and accept each program related to empowerment, such as the KWT program in making organic fertilizer. And the KWT program which is an effort to involve women in improving agricultural businesses in the village of Paledah. Today's peasant women must have the opportunity to develop their potential. In addition, farmers are encouraged to work together and work together to encourage and support other poor communities of farmers.

Overall the efforts made by the program to empower the farming community are good and positive, for example in the Pelatihan Anak Tani Remaja (PATRA) which focuses on youth regeneration of farmers so that the younger generation is not proud of being interested in agricultural activities. This activity was attended by a growing number of teenage participants. As said by the founder of the PATRA program "Profesi patani dianggap rendah sarta kirang bergengsi jang kebanyakan anak anom ayeuna. Biasana generasi anom anu janteun patanipedah kapaksa sarta teu aya pilihan pagawean sanes. Lamun masalah ieu lumangsung teras-menerus mangka regenerasi patani sesah pisan diwujudkeun. Lami-kalamian patani di Desa Paledah anu umurna kolot bade nilar nanging teu aya gagantina anu ngajalankeun profesi minangka patani. Ku margi eta program PATRA digagas kanggo ngarangkul, ngaberdayakeun, sarta ngajak generasi anom dina ngokolakeun widang tani" Empowerment is not only the process of providing power or strength to weak parties or communities, but empowerment is more on preparing the community in the form of resources, opportunities, knowledge and expertise to increase the capacity of the community in determining the future, as well as participating and influencing life in the community itself. So that through empowerment, the community has the expertise and power in running and building their own lives [10].

In community empowerment through programs it cannot be done instantly, especially heterogeneous and heterogeneous farming communities that have different 
interests between one another. Coupled with the still unfamiliar farmers with the concept of communitycentered development or community empowerment. Stages in the process of community empowerment through the program include the stages of knowledge from the community to know the needs and weaknesses of the community that is the focus of empowerment. After the community has the knowledge, the next step is awareness and understanding, because with awareness and understanding of the shortcomings of the community will help in empowerment, so that it can be discussed related to community empowerment that must be done. The next stage can be done planning the results of deliberations and deliberations to be able to better utilize the local potential of the community. Utilization of local potential, both human resources and natural resources can alleviate the empowerment of the community, so that it can make the habituation of the community to take advantage of local potential. The next stage is assistance and evaluation for the success and sustainability of community empowerment.

Overall through 12 indicators of community empowerment is very good, can be described the success of community empowerment in each of these programs: (1) the level of participation, farmers are always present and follow the program without coercion and run the program well. (2) expressing opinions, farmers dare to express opinions in front of the community in the interest of all and always provide input and proposals in programs and activities. (3) change of consciousness, realize the root of every problem of community empowerment and realize the importance of empowerment for a better life. (4) taking action, conscience moved to play an active role in every program and activity, always supporting every empowerment program, always contributing in any case to the success of programs and activities. (5) concern \& cooperation, always thinking to prioritize shared needs in programs and activities, always inviting others or working in groups in program activities and activities, always working with the community to empower underprivileged communities through programs. (6) creativity, always having new ideas and thoughts in supporting community empowerment through programs, always utilizing the potential and natural resources they have. (7) setting new goals, always thinking about solving and overcoming the problem of empowering the farming community in the surrounding environment, compiling concepts to utilize the potential that is owned to be empowered, always sacrificing for empowerment in the surrounding environment. (8) negotiating, negotiating and discussing opinions in delivering a program so that it can be carried out, always negotiating with outside parties / private parties to help empower the community through the program. (9) satisfaction, satisfied with the impact of activities and programs in empowering the community so far, programs and activities are very appropriate in empowering the community, programs and activities can increase the spirit of the community to be more independent. (10) self confidence, confidence and trust in the program in empowering the community, through programs and activities the community becomes confident in their own abilities. (11) managerial skills, after participating in activities the ability to utilize and cultivate their potential increases, after participating in activities more able to manage managerial well. (12) decision-making, decisions are always based on shared interests, farmers dare to be responsible in every decision taken related to community interests, decision-making is always based on the results of deliberations and consensus with other farming communities.

\subsection{Farmer's Community Social Capital}

Strengthening social capital is needed by farmers in developing their actual and potential resources from social networks. Farmers participate in several social networks in the form of program activities, namely Kelompok Tani Sejahtera (KTS), Kelompok Wanita Tani (KWT), Pelatihan Anak Tani Remaja (PATRA), Pengembangan Usaha Agribisnis Perdesaan (PUAP), and Gapoktan (Gabungan Kelompok Tani). This continues in the form of mutual recognition and mutual recognition among farmers in the form of collective support

Rural empowerment in the future requires a new approach. Strengthening social capital in rural development can be seen as a very important approach to reform. If rural development is not accompanied by the strengthening of institutions and organizations, the most community participation in rural areas, and the empowerment of the people's economy, then whatever programs in rural areas are implemented it will be difficult to achieve the expected results. In an organization, social capital is needed for the survival of the organization and the achievement of objectives. It requires at least a social network in which there are members with a relationship of mutual trust, close, mutual and beneficial [17].

The elements of social capital that are considered important to be developed in the empowerment of rural communities are the competence of human resources or human capital, social management and strong civil society organizations, unequal social structures, strong local leadership, strong moral and legal systems strong, and good governance. That in an organization requires a social capital in the form of connections between individuals or in other words social networks, norms, reciprocal relationships and close trust [18].

In this case, social capital is divided into four types:

a) A bond of solidarity

There are emotional and moral feelings that are formed in relationships between farmers or groups based on mutual trust, common goals and ideals, the presence of solidarity and sense of responsibility. The relationship between farmers in group activities underlies a shared attachment in life supported by moral values and beliefs that live in the farming community itself. The form of farmers' solidarity found was in the form of mutual cooperation. It can be seen that the KTS, PUAP and Gapoktan program activities are reviving leuit (rice storage) as a source of community food. The program also seeks to assist farmers in mutual cooperation activities in the form of chaotic, namping, 
mopok, ngawuluku, ngalepa, stocking, naplak, babut, tandur, ngarambet, ngagemuk, harvest, ngarit and ngagebot. The existence of the program is the glue to unite citizens with one another. The sense of solidity, loyalty, and community togetherness is getting stronger. There are organizations of groups of individuals who are heterogeneous so they must learn to adapt and prioritize a sense of solidarity [19].

b) Type of reciprocal exchange

The reciprocity relationship carried out by farmers in the program occurs in several activities. This reciprocal network produces benefits for farmers from their participation in program activities. Neither can the program benefit from having farmers as program implementers. The collaboration is expected to achieve the objectives of farmers' welfare. To realize this expectation, empowerment agencies and all elements of the program always hold fast to the shared goals and ideals and therefore cooperation and trust in each other is very important. This form of reciprocity is like the PUAP program which has a farmer cooperative. The principle of this cooperative is based on kinship and aims to help farmers run farming more easily. Farmers can easily borrow capital to buy seeds, fertilizers, farming tools, pesticides, etc. In addition, farmers can also save money as savings and savings can be taken at any time if farmers need.

c) Types of values and social norms

In every program activity carried out by farmers, it must be based on ideas and values, noble morals, and commitments that are adhered to by all members through contractual relationships. Farmers' values and norms are felt to be very strong, this is because the farming community still tends to uphold their culture and customs. Most farmers in their daily activities also highly uphold values and norms such as, uphold ethics, greet each other, respect each other, speak and behave politely, help one another, cooperate with each other, and maintain good manners. Values and norms have a role as a source of inspiration and motivation to do something that is considered good, as a binder of solidarity between farmers, as a guide and controller, and as a basic force to maintain the integrity and survival of farmers. Norms that are able to produce social capital in society must pay attention to aspects of honesty, fulfillment of duties and willingness to help each other and mutual commitment. Norms can be sourced from religion, moral standards, and secular standards as well as professional codes of ethics. Norms are built and developed based on the history of past collaborations and are applied to support the cooperative climate. Norms can be pre-conditions or products of social trust.

d) Cultivate trust

Trust is important in social capital because it helps manage complexity, helps develop action capacity, enhances collaboration and enhances organizational learning abilities. The keys that are very important in building high trust in organizations are achieving results, acting with integrity, and demonstrating attention. As a resource, social capital with aspects of trust, networks, and values can provide strength or power and be able to streamline various activities in a number of social conditions in society, both within the family, education, and within the bureaucracy or government. The involvement of individuals with social trust in a group or network is social capital to be able to develop their potential and abilities [20].

\section{CONCLUSION}

Strengthening social capital in empowering the village farmers community is carried out in several forms of programs, namely Kelompok Tani Sejahtera (KTS), Kelompok Wanita Tani (KWT), Pelatihan Anak Tani Remaja (PATRA), Pengembangan Usaha Agribisnis Perdesaan (PUAP), and Gapoktan (Gabungan Kelompok Tani).

Overall, the program has succeeded in empowering the farming community who feel that their quality of life is improving. Farmers tend to be more empowered by increasing knowledge, skills and expertise in agriculture. Farmers are guided to be more independent, problemsolving abilities, able to think, and act in accordance with their experiences found in program activities. Seen from the 12 indicators of community empowerment, empowerment of farmers through the program has been very good including: levels of participation, expression of opinions, changes in awareness of taking action, care \& cooperation, creativity, preparation of new negotiation goals, satisfaction, self-confidence, managerial skills, and collection decision.

This empowerment is also strengthened by social capital which is considered important to be developed in empowering farming communities, namely human resource competency, human management, and strong civil society organization, unequal social structure, unequal local leadership. Strong moral and legal system, and good governance. Look at the types of bonds of solidarity, reciprocity ties, social values and norms, and fostering trust.

\section{ACKNOWLEDGMENT}

Praise God Almighty, for the presence of plenty of mercy and his grace, so that the writer can complete the research with the title: Strengthening Social Capital in Empowering Village Farming Communities in Padaherang District, Pangandaran Regency

Appreciation and thanks to the husband Muhamaad Almuharromy and sincere setulus-beloved Father and a beloved Mother Lisdarwani Nasution who have put all our love and affection and attention to moral as well as material. May Allah SWT always bestow grace, health, gifts and blessings in the world and in the hereafter over budi good that has been given to the author.

\section{REFERENCES}

[1] E. M. Setiadi and U. Kolip, Pengantar Sosiologi, Jakarta: Kencana Prenada Group, 2011. 
[2] Yoo, "Collaborative Community Empowerment: An Illustration of a Six-Step Process," Journal of Leadership \& Organizational Studies 2015, vol. 22 (4), pp. 433-442, 2004.

[3] Talundu, ". Kondisi Sosial Ekonomi Masyarakat Petani Sawah Di Desa Tanah Harapan Kecamatan Palolo Kabupaten Sigi," E Journal Geo UNTAD, 2015.

[4] Undang-Undang Republik Indonesia Tentang Desa, 2014.

[5] Ripoll, ". Rural transformation, cereals and youth in Africa: What role for international agricultural research?," Sagepub, vol. 46 (3), pp. 168-177, 2017.

[6] Soetrisno, Paradigma baru Pembangunan Pertanian Sebuah Tinjauan Sosiologis, Yogyakarta: KANISIUS, 2002.

[7] Badan Pusat Statistik Provinsi Jawa Barat, 2018.

[8] H. P. M. A. F. \&. P. P. Binswanger-Mkhize, "Struktural Transformation and African Agriculture," Global Journal of Emerging Market Economies, vol. 2 (2), pp. 113-152, 2010.

[9] Rahman, "Microdeterminants of poverty among the farming population in Bangladesh," Rural Development at the School of Geography, Earth and Environmental Sciences, Unh PL4 *AA, UKiversity of Plymouth, Drake Circus, Plymou, vol. 38 (4), pp. 349-355, 2009.

[10] Anwas, Pemberdayaan Masyarakat di Era Global, Bandung: CV Alfabeta, 2014.

[11] Becker, "An innovative geographical approach: health promotion and empowerment in a context of extreme urban poverty," IUHPE - PROMOTION \& EDUCATION SUPPLEMENT 3, 2005.
[12] J. W. cresswell, Research Design Pendekatan Kualitatif, Kuantitatif, dan Mixed, Yogyakarta: Pustaka Pelajar, 2010.

[13] Arikunto, Manajemen Penelitian, Jakarta: Rineka Cipta, 2006.

[14] C. a. Soulsby, "Organization-Community embeddedness: The Social Impact of Enterprise Restructuring in the Post-Communist Czech Republic," Sage Social Science Collections, 1998.

[15] J. Tittenburn, "Social capital: Neither social, nor capital. Social Science Information," vol. 53 (4), pp. 453-461, 2014.

[16] -, Undang-Undang Republik Indonesia, 2013.

[17] U. \&. C. F. George, "Social capital and employment: South Asian women's experiences," Affilia - Journal of Women and Women and Social Work, vol. 24 (4), pp. 394-405, 2009.

[18] D. R. R. \&. M. K. Hawes, "Social capital in the 50 states: Measuring state-level social capital," State Politics and Policy, vol. 13 (1), pp. 121-138, 2013.

[19] J. W. Kapeller, "The Grounds of Solidarity: From Liberty to loyality," European Journal of Social Theory, vol. 16 (4), pp. 476-491, 2013.

[20] Song, "Social Capital and Psychological distress," Journal of Health and Social Behavior, vol. 52 (4), pp. 478-492, 2011. 